\title{
Reading Habits of Education Majors
}

\author{
Matthew Capps and SuHua Huang \\ Midwestern State University
}

\begin{abstract}
This study is a follow up to the Reading Habits of College Students in the USA, which employed a convergent mixed-method research design to investigate reading habits of American College Students. A total of 395 students majoring in education voluntarily participated in the study by completing a self-reported survey. The significant contributing factors to time spent on Academic Reading include ethnicity; time spent on Extracurricular Reading, engagement with magazines, engagement with non-major academic books, and bestsellers. The significant contributing factors to time spent on Extracurricular Reading include ethnicity, time spent on Academic Reading, time spent on the internet, engagement with novels/comic books, and engagement with bestsellers.
\end{abstract}

\section{Introduction}

It is common knowledge that teachers are expected to be good reading role models, inspire a love of reading in their students, and show effective reading strategies in their classroom [1]. Preservice teachers should also be expected to develop good reading habits and interests because their reading attitudes may affect their students' achievements [12]. Thus, we assume teachers must be readers and writers so they, in turn, can be effective teachers of literacy [6]. Teacher training programs also assume that those choosing to be teachers must possess adequate reading skills to deal with teaching requirements [7].

Pre-service teachers' reading activities for their future classrooms have received more attention; most notably the 2001 No Child Left Behind Act, has increased demands on teachers to improve students' academic achievement levels [25]. Pressure on teacher education programs to improve training for pre-service teachers is necessary to enhance instructional practices in the public schools. Preparing pre-service teachers to be good teachers of reading is very important because they are expected to select strategies, materials, and resources for the needs of their classrooms and transfer them to future teaching contexts [4].

However, research indicates that minimal information is available regarding pre-service teacher education in the specific areas of teaching [19]. As of 2000, when the NRP completed its indepth search of the literature on reading research, only seven experimental articles had been published in peer-reviewed journals on the topic of pre-service teacher reading education [13]. The literature contains even less research focused on the reading interests of pre-service teachers, which would certainly influence classroom practices encouraging reading for all grade levels of students. As a result, the studies of reading interests and the resulting impact on pre-service teachers' instructional practices have been either inconsistent or limited. Investigation of the impact of preservice teachers' reading interests on instructional practices is certainly warranted.

\section{Literature Review}

A small number of published articles have contributed some general information about varying factors that have influenced college students' time spent reading. Some of these have included pre-service teachers. Some research emphasized academic reading and other studies focused on recreational/extracurricular reading. Blackwood [5] and her colleagues studied the pleasure reading habits of college seniors $(n=333)$ enrolled at a small liberal arts public university. The findings indicated that $88 \%$ of the students reported reading for pleasure and most reported spending more time reading during vacations than when classes were in session. Both male and female students spent about 2.5 hours per week reading during school terms and slightly more during vacations.

Research has further investigated types of reading materials college students would prefer to read. Daisey [10] surveyed 82 pre-service teachers in a required secondary content area literacy course. The participants indicated a wide variety of favorite reading materials. Selections included best sellers such as Stephanie Meyer's Twilight, and Lance Armstrong's It's Not About the Bike.

On the contrary, literature suggests that preservice teachers have some important reading problems [1]. Bean [4] reported that only $62 \%$ of his secondary pre-service teachers could describe 
how they were going to foster the love of reading in their future students. Applegate and Applegate [2] focused on reading interests and attitudes of 195 sophomores majoring in elementary education. They found that many pre-service teachers were not avid readers even though the public expected teachers to model active reading habits as a positive influence on their students. Powell-Brown [21] indicated that his pre-service teachers never liked to read. Cunningham and his colleagues [8] showed that for the majority of pre-service teachers evaluated, their knowledge levels are positive, but they demonstrated limited knowledge of children's literature, and a variety of reading strategies for different content areas [8].The results also showed that pre-service teachers are often unaware of what they know and do not know.

Some research found that pre-service teachers' early reading experiences may affect their reading habits and their future students. O' Callaghan's study [20] suggested that $54.3 \%$ of the 195 participants were classified as unenthusiastic about reading. Some research further indicated deeply rooted negative attitudes toward the act of reading. Daisey [9] surveyed 124 pre-service teachers and they were asked to rate the statement "throughout my life I have enjoyed reading," on a 10 point scale, the mean was 7.27. These pre-service teachers also reported the most negative influence when they were in high school. Lesley and her research team [17] also further suggested that preservice teachers rarely made text to world connections and they relied on text for self-prior knowledge connections. Other evidence [14] indicates that pre-service teachers spent less time in reading when compared with other majors. The results of Huang and colleagues study suggested a need to further investigate what factors influenced pre-service teachers' reading habits [14].

One factor that merits investigation is the use of Internet and social media, which touch many aspects of college students' academic lives. Mokhtari, Reichard, \& Gardner [18] surveyed 539 college students. The study reported that $85 \%$ of respondents spent 12.35 hours per week on the Internet. The findings indicated that students enjoyed 'browsing the Internet' or watching television instead of recreational and academic reading.

Research shows today's college students utilize online resources for "a wide variety of academic purposes" including online libraries and databases [16]. The World's Library Connected (OCLC) [22] states that college students, as compared to other groups, are the most familiar with all the electronic resources, and show a substantially "higher use of electronic magazines/journals, online databases, and electronic books" (p.14). A follow-up study also reported that $90 \%$ of college students believed that online database and electronic magazines/journals were worthwhile sources of information [23].

\section{Methods and Methodology}

The primary aim of the present study was to employ a survey research method to investigate reading habits and practices of students majoring in Education. Two major research questions were addressed in this study.

1. What variables influence how much time Education majors spend on Academic Reading?

2. What variables influence how much time Education majors spend on Extracurricular Reading?

\subsection{Settings and Participants}

The study took place in a public liberal arts university in the Southwestern U.S. The participating university is organized into six colleges (Education, Business, Fine Arts, Health Science, Social Science, and Science and Math). Student enrollment averages around 6,000.

A total of 422 (45 male and 377 female) preservice teachers participated in the study during the fall semester of the 2013 academic year by completing a self-reported survey. The ethnic groups included: Caucasian (85\%), African American (6.5\%), Native Americans (2\%), and Hispanics (6\%), Asians (0.5\%).

\subsection{Instrument}

The researchers used a survey which mainly asked students how much time they dedicated to different activities each week, including academic reading, extracurricular reading, part-time or fulltime job, Internet (browsing websites), sleeping, and socializing with others. The survey also asked about the types of materials students would prefer to read, including online reading and conventional texts or formats for magazines, novels/comic books, non-major academic books, and bestsellers.

\subsection{Procedures}

Before the study began, the researcher sent emails to the university's instructors asking for permission to solicit students to participate in the study. In the following weeks, the researcher and assistants visited participating classrooms and distributed surveys to the students. Brief instructions were given explaining how to respond to each question before surveys were given to the students. Students were assured that all data 
collected would remain confidential and would be used for research purposes only. Any student who was not willing to participate in this study was allowed to return a blank survey.

\section{Analysis of Findings}

Data that collected from student majoring in Education, included time spent on academic reading, extracurricular reading, part-time jobs, sports, internet activity, sleeping and socializing. In addition, data was collected regarding the extent to which students were reading online reading materials, magazines, novels/comic books, nonmajor academic books and bestsellers. Finally, questions about reading habits were asked regarding; when and where students like to read and how often parents had read to the participant. Additional data was collected about the participants' classification (Freshman, Sophomore, etc...), gender, and ethnicity.

Initially a bivariate correlation was conducted to determine the relationship between the two major types of reading in this study; academic and extracurricular. Evidence suggests a significant, positive correlation $(\mathrm{r}=.233, \mathrm{p}<.001)$ between academic reading and extracurricular reading. A positive correlation also exists between academic reading and reading of online materials $(r=.165$, $\mathrm{p}<.01)$ and non-major academic books $(r=.308$, $\mathrm{p}<.001)$. Extracurricular reading is positively correlated to time spent on the internet $(r=.165$, $\mathrm{p}<.01)$, reading online reading materials $(\mathrm{r}=.138$, $\mathrm{p}<.01)$, reading novels/comic books $(\mathrm{r}=.437$, $\mathrm{p}<.001)$, and bestsellers $(\mathrm{r}=.508, \mathrm{p}<.001)$.

Two questions about current reading habits were asked of the participants, including where (classroom, library, bookstore, home, other) and when (morning, afternoon, evening, midnight, weekend, other). The majority of respondents indicated they read at home $(83.8 \%)$ and in the evening $(58.2 \%)$. A Kruskall Wallis was conducted to determine if time or location was a factor in the amount of time spent on Academic and Extracurricular reading. Results indicate that no significant difference in time spent on Academic Reading exists depending on when $(\mathrm{p}=.103)$ or where $(p=.935)$ students did not read nor does it seem to matter when $(p=.181)$ or where $(p=.820)$ on Extracurricular Reading.

In addition, participants were asked how often their parents read to them (never, seldom, sometimes, or frequently). The majority of the participants indicated their parents read to them frequency $(53.2 \%)$, but the concept of reading to children also correlates to other data collected. Reading to children appears to be positively correlated to choosing to read bestsellers $(r=.165$, $\mathrm{p}<.01)$, novels/comic books $(\mathrm{r}=.174, \mathrm{p}<.001)$, and magazines $(\mathrm{r}=.149, \mathrm{p}<.01)$. The rate at which parents read to education majors is not equally distributed, indicating that as a whole, the parents of education majors read to their children frequently. However, further analysis indicates that 50-60\% of Caucasian, African American and Asian students reported their parents read to them frequently, but that is not the same among Native Americans or Hispanics.

A bivariate correlation was conducted to determine the relationship between the frequency at which parents read to their children and ethnicity, time spent on academic reading and time spent on extracurricular reading. There is no correlation between the frequency at which parents read to the participants and the time spent on neither academic reading nor extracurricular reading. However, there is a negative. To determine if a significant difference exists between these ethnic groups and the frequency at which parents read to children, a non-parametric Kruskall Wallis was conducted. A significant difference does exist between the groups. Hispanic students reported significantly lower frequency of being read to by parents $(\mathrm{p}<.001)$ than any other group.

Despite the indication that Hispanics report that parents read less to them than any other group, only Asians report spending a significant amount of more time than Caucasian, African American, and Hispanics on academic reading $(\mathrm{p}<.01)$ and more time than all groups except those classified as Other on extracurricular reading $(\mathrm{p}<.01)$.

Multiple linear regression was employed to help determine which of five variables including, extracurricular reading (ER), gender $(G)$, ethnicity (ETHNICITY), number of hours worked in a parttime job (PJ), hours spent on the internet (INT), hours sleeping (SL), hours spent socializing (SO), hours spent on sports (SP), engagement with Online Reading Materials (ON), magazines (Mag), Novels/Comic Books (NC), Non-major Academic books (NAC), Bestsellers (BE), when participants read $(\mathrm{W})$, where participants $\operatorname{read}(\mathrm{H})$, and how frequently parents read to participants $(\mathrm{O})$ could be used to predict the dependent variable, Academic Reading. The sixteen variables together produced an adjusted $R^{2}$ of $.230(\mathrm{~F}(16,378)=8.273, \mathrm{p}<.001)$ for the predication Academic Reading. The predictor with the lowest non-significant regression coefficient (SL, $\beta=-.002, \mathrm{p}=.951$ ) was removed and another regression analysis was conducted which had an adjusted $R^{2}$ of $.259(\mathrm{~F}(15,379)=8.848$, $\mathrm{p}<.001)$ for the prediction Academic Reading. The next predictor with the lowest non-significant regression coefficient $(\mathrm{H}, \beta=.005, \mathrm{p}=.959)$ was removed and another regression analysis was conducted which had an adjusted $R^{2}$ of $.232(\mathrm{~F}$ $(14,380)=9.504, \mathrm{p}=.001)$. The next predictor with the lowest non-significant regression coefficient 
(PJ, $\beta=-.009, \mathrm{p}=.693)$ was removed and another regression analysis was conducted which had an adjusted $R^{2}$ of .234 (F $\left.(13,381)=10.246, \mathrm{p}=.001\right)$. The next predictor with the lowest non-significant regression coefficient $(\mathrm{O}, \beta=.040, \mathrm{p}=.544)$ was removed and another regression analysis was conducted which had an adjusted $R^{2}$ of .235 (F $(12,382)=11.088, \mathrm{p}=.001)$. The next predictor with the lowest non-significant regression coefficient (SO, $\beta=-.070, p=.802$ ) was removed and another regression analysis was conducted which had an adjusted $R^{2}$ of .237 (F $(11,383)=$ $12.120, \mathrm{p}=.001)$. The next predictor with the lowest non-significant regression coefficient $(\mathrm{NC}, \beta=-$ $.060, \mathrm{p}=.407)$ was removed and another regression analysis was conducted which had an adjusted $R^{2}$ of $.238(\mathrm{~F}(10,384)=13.273, \mathrm{p}=.001)$. The next predictor with the lowest non-significant regression coefficient $(\mathrm{G}, \beta=-.139, \mathrm{p}=.440)$ was removed and another regression analysis was conducted which had an adjusted $R^{2}$ of .238 (F $(9,385)=14.697$, $\mathrm{p}=.001)$. The next predictor with the lowest nonsignificant regression coefficient (SP, $\beta=.068$, $\mathrm{p}=.184$ ) was removed and another regression analysis was conducted which had an adjusted $R^{2}$ of $.237(\mathrm{~F}(8,386)=16.280, \mathrm{p}=.001)$. The next predictor with the lowest non-significant regression coefficient (W, $\beta=-.101, \mathrm{p}=.074)$ was removed and another regression analysis was conducted which had an adjusted $R^{2}$ of $.259(\mathrm{~F}(7,387)=18.043$, $\mathrm{p}=.001)$. The next predictor with the lowest nonsignificant regression coefficient (INT, $\beta=.041$, $\mathrm{p}=.061$ ) was removed and another regression analysis was conducted which had an adjusted $R^{2}$ of $.227(\mathrm{~F}(6,388)=20.330, \mathrm{p}=.001)$. The next predictor with the lowest non-significant regression coefficient $(\mathrm{ON}, \beta=.141, \mathrm{p}=.053)$ was removed and another regression analysis was conducted which had an adjusted $R^{2}$ of $.222(\mathrm{~F}(5,389)=$ 23.447, $\mathrm{p}=.001)$. Therefore the significant contributing factors to time spent on Academic Reading include ethnicity, time spent on extracurricular reading, engagement with magazines, engagement with non-major academic books, and bestsellers.

Multiple linear regression was employed to help determine which of 16 variables, including, academic reading (AR), gender (G), ethnicity (ETHNICITY), number of hours worked in a parttime job (PJ), hours spent on the internet (INT), hours sleeping (SL), hours spent socializing (SO), hours spent on sports (SP), engagement with Online Reading Materials (ON), magazines (Mag), Novels/Comic Books (NC), None-major Academic books (NAC), Bestsellers (BE), when participants read $(\mathrm{W})$, where participants $\operatorname{read}(\mathrm{H})$, and how frequently parents read to participants $(\mathrm{O})$ could be used to predict the dependent variable,
Extracurricular Reading. The sixteen variables together produced an adjusted $R^{2}$ of $.348[\mathrm{~F}$ $(16,378)=14.138, p<.001]$ for the prediction of Academic Reading. The predictor with the lowest non-significant regression coefficient $(\mathrm{ON}, \beta=-$ $.001, \mathrm{p}=.990)$ was removed and another regression analysis was conducted which had an adjusted $R^{2}$ of $.350(\mathrm{~F}(15,379)=15.121, \mathrm{p}<.001)$ for the prediction of Academic Reading. The next predictor with the lowest non-significant regression coefficient $(H, \beta=-.034, p=.611)$ was removed and another regression analysis was conducted which had an adjusted $R^{2}$ of $.351(\mathrm{~F}(14,380)=16.214$, $\mathrm{p}=.001)$. The next predictor with the lowest nonsignificant regression coefficient $(\mathrm{PJ}, \beta=-.008$, $\mathrm{p}=.617$ ) was removed and another regression analysis was conducted which had an adjusted $R^{2}$ of $.352(\mathrm{~F}(13,381)=17.476, \mathrm{p}=.001)$. The next predictor with the lowest non-significant regression coefficient $(\mathrm{O}, \beta=-.029, \mathrm{p}=.565)$ was removed and another regression analysis was conducted which had an adjusted $R^{2}$ of .353 (F $(12,382)=18.938$, $\mathrm{p}=.001)$. The next predictor with the lowest nonsignificant regression coefficient (SL, $\beta=.019$, $\mathrm{p}=.405$ ) was removed and another regression analysis was conducted which had an adjusted $R^{2}$ of $.354(\mathrm{~F}(11,383)=20.613, \mathrm{p}=.001)$. The next predictor with the lowest non-significant regression coefficient (SO, $\beta=-.020, \mathrm{p}=.384$ ) was removed and another regression analysis was conducted which had an adjusted $R^{2}$ of .354 (F $(10,384)=$ $22.612, \mathrm{p}=.001)$. The next predictor with the lowest non-significant regression coefficient (MAG, $\beta=$ $.060, p=.274$ ) was removed and another regression analysis was conducted which had an adjusted $R^{2}$ of $.354(\mathrm{~F}(9,385)=24.979, \mathrm{p}=.001)$. The next predictor with the lowest non-significant regression coefficient (SP, $\beta=.044, p=.267$ ) was removed and another regression analysis was conducted which had an adjusted $R^{2}$ of $.354(\mathrm{~F}(8,386)=27.930$, $\mathrm{p}=.001)$. The next predictor with the lowest nonsignificant regression coefficient $(\mathrm{W}, \beta=.067$, $\mathrm{p}=.114$ ) was removed and another regression analysis was conducted which had an adjusted $R^{2}$ of $.351(\mathrm{~F}(7,387)=31.440, \mathrm{p}=.001)$. The next predictor with the lowest non-significant regression coefficient (NAC, $\beta=.097, p=.066$ ) was removed and another regression analysis was conducted which had an adjusted $R^{2}$ of .347 (F $(6,388)=$ $35.893, \mathrm{p}=.001)$. The next predictor with the lowest non-significant regression coefficient $(G, \beta=.241$, $\mathrm{p}=.067$ ) was removed and another regression analysis was conducted which had an adjusted $R^{2}$ of $.343(\mathrm{~F}(5,389)=34.624, \mathrm{p}=.001)$. Therefore the significant contributing factors to time spent on Extracurricular Reading include Ethnicity, time spent on Academic Reading, time spent on the 
internet, engagement with novels/comic books, and engagement with bestsellers.

\section{Discussion}

This study aimed to investigate independent variables that influence the academic and extracurricular reading habits of students majoring in Education. Overall, the findings provided answers to the two major research questions of this study and also demonstrated that online reading is embedded in the reading practices and academic lives of education major students.

Findings of the zero-order correlation supported regression model analysis, indicating that the academic reading was correlated to online material selection and non-major academic book selection. Extracurricular reading was found to be positively correlated to time spent on the internet, reading online materials, novels/comic books and bestsellers. The evidence would suggest that students majoring in education limit academic reading to more narrow genres, than what is selected for extracurricular reading. It should be noted that online material is the only genre correlated to both types of reading, which supports recent findings that the Internet has a sufficiently important role in reading and has been among the major reading resources [15]. The findings of regression analysis indicate that ethnic background, selection of online reading, non-major academic books and bestsellers have an impact on time spent on academic/extracurricular reading.

The study indicates that ethnicity appears to play a significant role in the development of reading habits of some students majoring in education. The majority of Hispanic respondents indicate their parents never read to them as children. The findings have confirmed that early literacy experiences have greatly influenced preservice teachers' reading attitudes and interests [20]. On the contrary, other respondents indicated that parents read to them anywhere between seldom and frequently (53\% of respondents). The results of the survey question did not specially indicate what made parents read less to Hispanics students. Further investigation, by using the qualitative method (e.g., interview students and parents) is needed to discover more about the relationship between ethnicity and time spent on reading.

To contribute more educational factors in the classroom, all levels of schools should continue to attract students of Hispanic or other ethnic heritages into the classrooms where teachers foster reading as a part of learning and curriculum. Educator preparation programs may consider a focus on the development of a children's literature curriculum and introduce new updated information about books from different types of genres so that pre-service teachers could know how to implement in their future classrooms. Teachers could also build up the multicultural and multi-social communities to promote reading for students with diverse backgrounds.

\section{Implications}

The results have indicated that the rapid online changes have resulted in literacy becoming more technologically oriented. Pre-service teachers in this study read online reading materials or information more than traditional textbooks or offline information. These new technologies not only influence pre-service teachers' learning and studying in the classroom, but also affect their reading habits and reading behaviors. Teaching and learning is not limited to traditional classrooms, students now can study and search for information anywhere with Internet access.

Technology has certainly changed our teaching and learning beyond the classroom walls. Accessing technology to gain knowledge and skills is also relevant to all levels of students. Due to the 'nature of ever-changing technology' college teachers also need to keep providing the currently available resources to students, creating a vision of continual technology integration in their classroom [24]. College professors need to recognize the power of technology in impacting college students' reading habits, and that adapting teaching instruction to meet the new generation of college students' educational needs is necessary. In contrast, technologies cannot replace the concepts of teaching scaffolding and traditional literacy practices; [3] therefore, college professors need to know how to promote the concept of 'learning to learn.' College teachers also need to use strategies that promote student reading motivation and selfefficacy in critical thinking and interpersonal skills within digital learning communities. Integrating technology to course content could foster students' reading interest and motivation to read.

Since easy access to reading materials plays a critical role in changing pre-service teachers' reading habits and interests, educational faculty members might consider encouraging pre-service teachers' to expand their reading practices by providing accessible online interesting reading materials or using social media tools for educational purposes such as building Facebook, Instagrm or other social media sites for teaching purposes for different classes.

Pre-service teachers are the most important sources for creating conditions in the classroom environment to promote future students' motivation to read and to learn [12]. Educational training programs should not assume pre-service teachers are avid readers. College professors shall give 
students a choice in selecting books they would like to read and to also encourage students to share their reading activities. This could enhance students' love of reading, which might be more important than the focusing on taking exams based on textbook materials.

\section{References}

[1] Akyol, H., \& Uluso(r)y, M. (2010). Pre-service teachers' use of reading strategies in their own readings and future classroom. Teaching and Teacher Education, 26, 878-884.

[2] Applegate, A. J., \& Applegate, M. D. (2004). The Peter effect: Reading habits and attitudes of preservice teachers. The Reading Teacher, 57, 554563.

[3] Berg, M. (2011). On the Cusp of Cyberspace: Adolescent's online text use in conversation. Journal of adolescent \& Adult literacy, 54(7), 485493.

[4] Bean, T. W. (1997). Preservice teachers' selection and use of content area literacy strategies. The Journal of Educational Research, 90(3), 154163.

[5] Blackwood, C., Flowers, S. S., Rogers, J. S., \& Staik, I. M. (1991, November). Pleasure reading by college students; Fact or fiction? Paper presented at the annual meeting of the Mid-South Education Research Association Conference, Lexington, KY.

[6]Brooks, W. G. (2007) Teachers as readers and writers and as teachers of reading and writing The Journal of Educational Research, 100, 177191.

[7] Conaway, B. J., Saxon, T. F., \& Woods, M. B. (2003). A comparison of the reading abilities of teacher candidates. The Teacher Educator, 39(1), $1-17$.

[8] Cunningham, A. E., Perry, K. E., Stanovich, K. E., \& Stanovich, P. J. (2004). Disciplinary early literacy. Annals of Dyslexia, 54, 139-68.

[9] Daisey, P. (2009).The reading experiences and beliefs of secondary pre-service teachers. Reading Horizons, 49(2), 167-190.

[10] Daisey, P. (2010). Secondary pre-service teachers remember their favorite reading experiences: Insights and implications for content area instruction. Journal of Adolescent \& Adult Literacy, 53(6). 678-687.

[11] Fox, S. (2002). The Pew Internet and America Life report. Retrieved from http://www.pewinTer net.org/Reports/2002/Online-Banking-2002.aspx.

[12] Graves, D. (2001). The Energy to Teach. Portsmouth, NH: Heinemann.

[13] Haverback, H., \& Parault, S. (2008). PreService reading teacher efficacy and tutoring: A review. Educational Psychology Review, 20, 237255.

[14] Huang, S. H., Capps, M., Black, J., \& Garza, M. (2014). Reading habits of college students in the United States. Reading Psychology, 35, 437467.

[15] Ito, M., Baumer, S., \& Bittanti, M., Boyd, D., Cody, R.,Herr, B. (2008). Hanging out, messing around, geeking out: living and learning in new media. Retrieved January 24, 2012, from digitalyouth.ischool.berkeley.edu/report

[16] Jones, S., Johnson-Yale, C., Millermaier, S., \& Perez, F. S. (2008). Academic work, the Internet and U.S. college students. Internet and Higher Education, 11, 165-177.

[17] Lesley, M., Watson, P., \& Elliot, S. (2007). "School" reading and multiple texts: examining the metacognitive development of secondary-level preserve teachers. Journal of Adolescent \& Adult Literacy, 51, 150-162.

[18] Mokhtari, K., Reichard, C., \& Gardner, A. (2009). The impact of Internet and television use on the reading habits and practices of college students. Journal of Adolescent \& Adults Literacy, 92(7), 609-619.

[19] National Reading Panel (2000). Teaching children to read: An evidence-based assessment of the scientific research literature on reading and its implication for reading instruction. Washington, DC: Author.

[20] O'Callaghan, C. (2001). Social construction of pre-service teachers' instructional strategies for reading. The Teacher Educator, 36, 265-281.

[21] Powell-Brown, A. (2003). Can you be a teacher of literacy if you don't love to read? Journal of Adolescent \& Adult Literacy, 47(4), 284-288. 
[22] OCLC (2005). Perceptions of libraries and information resources: A report to the OCLC members. Dublin, OH: OCLC. Retrieved December 28, 2012 from

http://www.oclc.org/reports/2005perceptions.htm

[23] OCLC(2010). Perceptions of libraries: context and community: A report to the OCLC members.

Dublin, OH: OCLC. Retrieved February 22, 2012

from http://www.oclc.org/reports/2012

perceptions.htm.

[24] Turbill, J., \& Murray, J. (2006). Early literacy and new technologies in Australian schools: Policy, research, and practice. In M. C. McKenna, L. D. Labbo, R. D. Kieffer, \& D. Reinking (Eds.), International handbook of literacy and technology (vol. 2, pp. 93-108). Mahwah, NJ: Lawrence Erlbaum.

[25]US Department of Education, Office of Elementary and Secondary Education. (2002). No child left behind. A desktop reference. Washington, DC. 